\title{
Natural Infestation of Onion Seed by Pantoea ananatis, Causal Agent of Center Rot
}

\author{
R. R. Walcott, Department of Plant Pathology, University of Georgia, Athens 30602; R. D. Gitaitis, Department of \\ Plant Pathology, University of Georgia, Coastal Plain Experiment Station Tifton 31793; A. C. Castro, Department \\ of Plant Pathology, University of Georgia, Athens 30602; F. H. Sanders Jr., Department of Plant Pathology, Uni- \\ versity of Georgia, Coastal Plain Experiment Station Tifton 31793; and J. C. Diaz-Perez, Department of Horticul- \\ ture, University of Georgia, Coastal Plain Experiment Station, Tifton 31793
}

\begin{abstract}
Walcott, R. R., Gitaitis, R. D., Castro, A. C., Sanders, F. H., Jr., and Diaz-Perez, J. C. 2002. Natural infestation of onion seed by Pantoea ananatis, causal agent of center rot. Plant Dis. 86:106-111.

An immunomagnetic separation and polymerase chain reaction (IMS-PCR) assay was used to detect Pantoea ananatis in naturally infested onion seeds. Using species-specific PCR primers and polyclonal antibodies, IMS-PCR consistently demonstrated detection thresholds of $10^{1}$ to $10^{3} \mathrm{CFU} / \mathrm{ml}$. There was no significant difference between the numbers of CFU recovered from onion seed wash by IMS (after repeated rinses) and by direct plating, indicating that IMS effectively captured $P$. ananatis cells from heterogeneous bacterial populations. Using IMS-PCR and IMS followed by plating on nutrient agar, P. ananatis was detected in $19.7 \%$ of onion seed samples harvested from two onion fields in which center rot developed naturally in 2000 . When planted in germination boxes, $53 \%$ of the seed samples that tested positive for $P$. ananatis produced seedlings with symptoms of center rot. There was no significant difference in germination between infested and noninfested seed samples. This is the first report of natural infestation and transmission of $P$. ananatis in onion seed.
\end{abstract}

Additional keywords: Erwinia ananas, E. herbicola

Center rot of onion (Allium cepa L.) was first observed in Georgia on Sweet Vidalia onions in May of 1997 (7). Yield losses due to center rot were estimated at 20 to $25 \%$, with some fields experiencing 80 to $100 \%$ loss. Center rot has occurred in commercial fields in Georgia every year from 1998 and 2001, but losses during these years were estimated at $10 \%$, with some losses occurring under postharvest conditions. The causal agent of center rot is Pantoea ananatis, a gram-negative, facultatively anaerobic bacterium formerly classified as Erwinia herbicola (syn. Erwinia uredovora) (18). A similar organism has been reported to cause disease on cantaloupe and pineapple $(3,4,16)$.

The sudden occurrence of center rot of onion in Georgia prompted investigation into potential sources of inoculum of the pathogen. An onion disease of similar description caused by Pantoea agglomerans (syn. E. herbicola) was reported in South Africa in 1981 (12), and since seed associated with the first outbreak in Georgia

Corresponding author: R. R. Walcott

E-mail: rwalcott@arches.uga.edu

Accepted for publication 8 October 2001.

Publication no. D-2001-1211-01R

(C) 2002 The American Phytopathological Society were produced in South Africa, one hypothesis was that the bacterium was introduced on infested seedlots. Similarly, outbreaks of center rot were also reported in Colorado and Michigan for the first time in 1997 (23; M. K. Hausbeck, personal communication), suggesting the inoculum source was widely distributed. Despite these anecdotal observations, there has been no direct evidence for infection of onion seed by, and subsequent transmission of, $P$. ananatis. However, there have been reports of seedborne $P$. ananatis in sudangrass and buckwheat $(2,14,15)$.

Identifying the primary source of inoculum is of critical importance for effective plant disease management. With recent increases in commercial onion seed production outside the United States, there is greater potential for introducing and disseminating plant pathogens on infested seedlots into regions of the United States where the pathogens have not previously been reported. However, this can be difficult to prove because of limited access to nontreated samples, and low and irregularly distributed pathogen populations within seedlots. In addition, conventional pathogen detection techniques may lack the sensitivity required to detect seedborne pathogens. The polymerase chain reaction (PCR) has been employed increasingly in the past 10 years to detect seedborne plant pathogens $(1,5,10,19)$. However, plant tissues, including seeds, contain compounds that inhibit DNA amplification, making detection of pathogens by conventional PCR difficult $(11,24)$. Recent innovations have improved the sensitivity and efficiency of PCR-based seed detection assays. In particular, immunomagnetic separation (IMS) utilizes small, superparamagnetic, polystyrene beads, coated with antibodies specific to target bacteria, to sequester the bacteria from heterogeneous mixtures of microorganisms (20). These immunomagnetic beads (IMBs) can be used to selectively concentrate and clean up target cells from which template DNA can be released for PCR amplification and subsequent detection. Viable CFU can also be recovered by plating the IMBs onto appropriate solid media. While IMSPCR has not been utilized extensively in plant pathology, high levels of detection sensitivity and efficiency have been demonstrated for detecting Acidovorax avenae subsp. citrulli in watermelon seeds and Xanthomonas axonopodis pv. citri in citrus tissues $(11,24)$. The goal of this research was to develop an IMS-PCR assay for $P$. ananatis and to use this assay to survey seedlots for the pathogen.

\section{MATERIAL AND METHODS}

IMS-PCR assay development. Polyclonal antiserum was developed for $P$. ananatis as described previously (24). The IgG fraction of the anti-Pantoea ananatis serum (anti-PNA) was purified using an AvidChrom Protein Antibody Purification Kit (Sigma, St. Louis, MO) to obtain a final protein concentration of $3.4 \mathrm{mg} / \mathrm{ml}$. Using purified anti-PNA antibodies (IgG fraction), indirect enzyme-linked immunosorbent assay (ELISA) was conducted on 24 bacteria (Table 1) to determine antibody specificity (17). ELISA results were determined using an automated microplate reader (Spectrum Rainbow, Tecan US INC., Research Triangle Park, NC). Specific PCR primers were designed based on nucleotide sequences of the 16S-23S rDNA internal transcribed spacer (ITS) region of a known isolate of $P$. ananatis. The ITS sequence was amplified using universal primer pair EC5/GS4 derived from Escherichia coli (9). Two microliters of DNA from boiled (15 min) cell suspensions containing ca. $10^{8} P$. ananatis $\mathrm{CFU} / \mathrm{ml}$ of ster- 
ile high-pressure liquid chromatography (HPLC)-grade water (J. T. Baker, Phillipsburg, NJ) was amplified in $25 \mu$ of PCR master mix containing $10 \mathrm{mM}$ Tris- $\mathrm{HCl}$ (pH 9.0), $50 \mathrm{mM} \mathrm{KCl,} \mathrm{0.1 \%} \mathrm{Triton} \mathrm{X-100,}$ $1.5 \mathrm{mM} \mathrm{MgCl} 2,0.2 \mathrm{mM}$ of each nucleotide (dATP, dCTP, dGTP, and dTTP), 25 pM of each primer, and 1 unit of Taq DNA polymerase (Promega, Madison, WI) per reaction. DNA amplification was carried out in a Mastercycler Gradient programmable thermal cycler (Eppendorf, Hamburg, Germany). The PCR conditions included denaturation at $95^{\circ} \mathrm{C}$ for $5 \mathrm{~min}, 30$ cycles of denaturation at $95^{\circ} \mathrm{C}$ for $30 \mathrm{~s}$, annealing of primers at $55^{\circ} \mathrm{C}$ for $30 \mathrm{~s}$, and elongation at $72^{\circ} \mathrm{C}$ for $30 \mathrm{~s}$. The PCR was completed after incubation at $72^{\circ} \mathrm{C}$ for $5 \mathrm{~min}$. The PCR amplicon was purified using an affinity column (Wizard PCR Preps DNA Purification System, Promega) and sequenced by the University of Georgia Molecular Genetics Instrumentation Facility (Athens, GA). Several oligonucleotide sequences were selected as potential PCR primers and tested in different combinations for their ability to specifically amplify DNA from $P$. ananatis. The oligonucleotide PanITS1 (5'-GTC TGA TAG AAA GAT AAA GAC-3') in combination with EC5 (5'CGG TGG ATG CCC TGG CA-3') (9) gave the highest degree of specificity to $P$. ananatis. The specificity of this primer set was determined by conducting PCR on crude whole-cell DNA from 28 different bacteria (Table 1). The PCR conditions for this screen were similar to those described above except that an optimum annealing temperature of $60^{\circ} \mathrm{C}$ was employed. Results of the PCR were determined by electrophoresis $(90 \mathrm{~V}$ for $1 \mathrm{~h}$ in $1 \times$ Tris acetate EDTA buffer) of $10 \mu \mathrm{l}$ of the PCR product on a $1 \%$ agarose gel, followed by staining with ethidium bromide and visualization with ultraviolet illumination.

Immunomagnetic beads (M-280 Dynal, Oslo, Norway) were coated with anti-PNA antibodies (IgG fraction), and IMS-PCR was conducted according to the methods described by Walcott and Gitaitis (24) with the following modifications: $3 \times 10^{6} \mathrm{IMBs}$ were used per reaction and immunocapture was conducted for $30 \mathrm{~min}$ rather than 15 $\min$.

Sensitivity of IMS-PCR and IMSplating. To determine sensitivity of detection, IMS-PCR and IMS-plating were conducted on onion seed extract to which different concentrations of $P$. ananatis were added. Onion seed extract was generated by crushing $2 \mathrm{~g}$ of seed in $60 \mathrm{ml}$ of sterile $0.1 \mathrm{M}$ phosphate buffered saline (PBS) in a stomacher laboratory blender (Seward Ltd., London, UK) for $30 \mathrm{~min}$. Seed debris was removed by passing the seed extract through two layers of cheesecloth, and the filtrate was passed through one layer of Whatman No. 1 filter paper (Whatman, Springfield Mill, UK). Six-milliliter aliquots of the filtrate were dispensed into 8- ml Pyrex glass screw-cap tubes (Corning Life Sciences, Acton, MA). To each of five vials of seed extract, $P$. ananatis was added to generate cell suspensions of $10^{4}, 10^{3}$, $10^{2}, 10^{1}$, and $0 \mathrm{CFU} / \mathrm{ml}$. To estimate the $P$. ananatis concentration in each dilution, 100- $\mu$ l aliquots from each vial were spread onto a nutrient agar plate. Plates were incubated for $48 \mathrm{~h}$ at $28^{\circ} \mathrm{C}$, and colonies of $P$. ananatis were enumerated. Each dilution was subjected to IMS as described above. On the final rinse, IMBs were resuspended in $20 \mu \mathrm{l}$ of sterile HPLC-grade water. Ten microliters of the IMBs were spread onto nutrient agar plates and incubated in the dark at $28^{\circ} \mathrm{C}$ for $48 \mathrm{~h}$, and colonies of $P$. ananatis were enumerated. The remainder of the IMBs $(10 \mu \mathrm{l})$ were boiled for $15 \mathrm{~min}$ to lyse captured cells of $P$. ananatis. DNA for PCR. This was conducted 12 times to estimate the reliability of the assay.

Detection of $P$. ananatis in naturally infested onion seed. In May 2000, 76 umbels were harvested from two experireleased by cell lysis was used as template

mental onion (cv. Sweet Vidalia) plots (Horticulture [43 umbels] and Blackshank [33 umbels] farms, Coastal Plain Experiment Station, Tifton, GA) in which center rot had developed naturally. Center rot incidence was visually estimated at $18 \%$ across both fields; however, no obvious symptoms were observed on the mother plants from which umbels were harvested. Seeds were manually extracted in June, and seeds from each flower were maintained as a separate lot. Seedlots were stored in plastic bags at $5^{\circ} \mathrm{C}$ and $50 \% \mathrm{RH}$ until they were processed. To test for $P$. ananatis, $1 \mathrm{~g}$ of seeds from each lot was crushed in $25 \mathrm{ml}$ of $0.1 \mathrm{M}$ PBS in a stomacher blender. The seed extract was passed through two layers of cheesecloth to remove debris, and the filtrate was centrifuged at 3,200 $\times \mathrm{g}$ for $15 \mathrm{~min}$. The pellet was resuspended in $10 \mathrm{ml}$ of $0.1 \mathrm{M}$ PBS buffer with $0.1 \%$ bovine serum albumin (PBS-BSA) and passed through one sheet of No. 1 filter paper. The filtrate was collected in a Pyrex screw-cap test tube, and

Table 1. Bacteria tested by polymerase chain reaction (PCR) with PanITS1/EC5 primers and indirect enzyme-linked immunosorbent assay (ELISA) with polyclonal antibodies generated against Pantoea ananatis

\begin{tabular}{|c|c|c|c|}
\hline Bacterium & Source ${ }^{a}$ & PCR results ${ }^{b}$ & ELISA results ${ }^{c}$ \\
\hline Acidovorax avenae subsp. cattleyae & RST & - & + \\
\hline Acidovorax konjaci & RST & - & + \\
\hline Acidovorax avenae subsp. citrulli & RRW & - & + \\
\hline Acidovorax facilis & RDG & - & + \\
\hline Burkholderia cepacia & RDG & - & - \\
\hline Burkholderia gladioli pv. allicola & RDG & - & $\mathrm{NT}^{\mathrm{d}}$ \\
\hline Ralstonia solanacearum & RRW & - & + \\
\hline Pseudomonas aeruginosa & RDG & - & - \\
\hline Pseudomonas coronofaciens & RDG & - & - \\
\hline Pseudomonas corrugata & RDG & - & + \\
\hline Pseudomonas viridiflava & RDG & - & - \\
\hline Pseudomonas marginata & RDG & - & - \\
\hline Pseudomonas syringae pv. lachrymans & RDG & - & + \\
\hline Pseudomonas syringae pv. phaseolicola & RDG & - & + \\
\hline Pseudomonas syringae pv. syringae & RDG & - & + \\
\hline Xanthomonas campestris pv. vesicatoria & RDG & - & + \\
\hline Xanthomonas campestris pv. raphini & RDG & - & + \\
\hline Xanthomonas campestris pv. campestris & RDG & - & - \\
\hline Agrobacterium radiobacter & RDG & - & - \\
\hline Pantoea agglomerans & RDG & - & + \\
\hline Pantoea ananatis & RDG & + & + \\
\hline Pantoea stewartii pv. stewartii & RDG & + & NT \\
\hline Erwinia carotovora subsp. carotovora & RDG & - & + \\
\hline Erwinia carotovora subsp. atroseptica & RDG & - & + \\
\hline Erwinia chrysanthemi & RDG & - & + \\
\hline Proteus vulgaris & RDG & - & NT \\
\hline Escherichia coli & RDG & - & NT \\
\hline Clavibacter michiganensis subsp. michiganensis & RDG & - & + \\
\hline
\end{tabular}

a Abbreviations for sources of bacterial isolates are as follows: RST = R. S. Stall (retired), Department of Plant Pathology, University of Florida, Gainesville, FL; RRW = R. R. Walcott, Department of Plant Pathology, University of Georgia, Athens; RDG = R. D. Gitaitis, Department of Plant Pathology, University of Georgia, Coastal Plan Experiment Station, Tifton.

${ }^{\mathrm{b}}$ Results of PCR conducted on DNA extracted from suspensions of each bacterium containing $10^{8}$ $\mathrm{CFU} / \mathrm{ml}$ of sterile, deionized, distilled water, determined spectrophotometrically (optical density of 0.3 at a wavelength of $600 \mathrm{~nm}$ ) using primers PanITS1/EC5. A positive sign (+) indicates that PCR resulted in the production of a 398-bp amplicon. A negative sign (-) indicates that no amplicon was produced, or the amplicon produced was not the appropriate size.

$\mathrm{c}$ The results of indirect ELISA conducted on cell suspensions containing ca. $10^{6} \mathrm{CFU} / \mathrm{ml}$ of each bacterium using polyclonal antibodies produced against $P$. ananatis. A positive sign (+) indicates an absorbance value that was twice the value of the negative control $(0.1 \mathrm{M}$ phosphate buffered saline) as determined by a microplate plate reader (wavelength $=405 \mathrm{~nm}$ ). A negative sign $(-$ ) indicates that absorbance values were less than twice the value of the negative control.

${ }^{\mathrm{d}} \mathrm{NT}$ indicates that ELISA was not conducted. 
$300 \mu \mathrm{l}$ (ca. $10^{6}$ IMBs) of anti-PNA coated IMBs were added. The tubes were incubated with continuous agitation for $30 \mathrm{~min}$ at $4^{\circ} \mathrm{C}$. The IMBs were rinsed twice with PBS-BSA, once with sterile distilled water, and then resuspended in $20 \mu \mathrm{l}$ of sterile HPLC-grade water. Ten microliters of IMBs were plated directly onto nutrient agar plates that were incubated for $48 \mathrm{~h}$ at $28^{\circ} \mathrm{C}$ and observed for the development of smooth, yellow colonies typical of $P$. ananatis. To confirm the identity of putative $P$. ananatis colonies, PCR was conducted on DNA extracted from bacterial colonies using PanITS1/EC5 primers. For further confirmation, colonies recovered were verified as facultative anaerobes by the Hugh-Leifson assay (13) and fatty acid methyl ester analysis $(6,21)$. Additionally, bacteria were tested for the ability to produce indole by spotting a loopful of a 1- day-old colony growing on tryptic soy broth agar (Difco, Beckton Dickinson Microbiology Systems, Sparks, MD) onto an indole indicator slide (BBL Dryslide, Beckton Dickinson and Co., Sparks, MD). The ability to produce indole distinguishes $P$. ananatis from Pantoea stewartii subsp. stewartii. The remaining $10 \mu \mathrm{l}$ of IMBs was boiled for $15 \mathrm{~min}$ to lyse captured bacterial cells. The DNA released from the cells was used for PCR with primers PanITS1/EC5. The number of seedlots infested with $P$. ananatis was determined by IMS-PCR and by IMS-plating on nutrient agar.

Seed germination and center rot transmission. To determine the percent germination and disease transmission of the onion seedlots, samples $(n=100)$ of seed from each lot were placed ( 25 seeds per dish) into petri dishes $(15 \mathrm{~mm}$ diame-

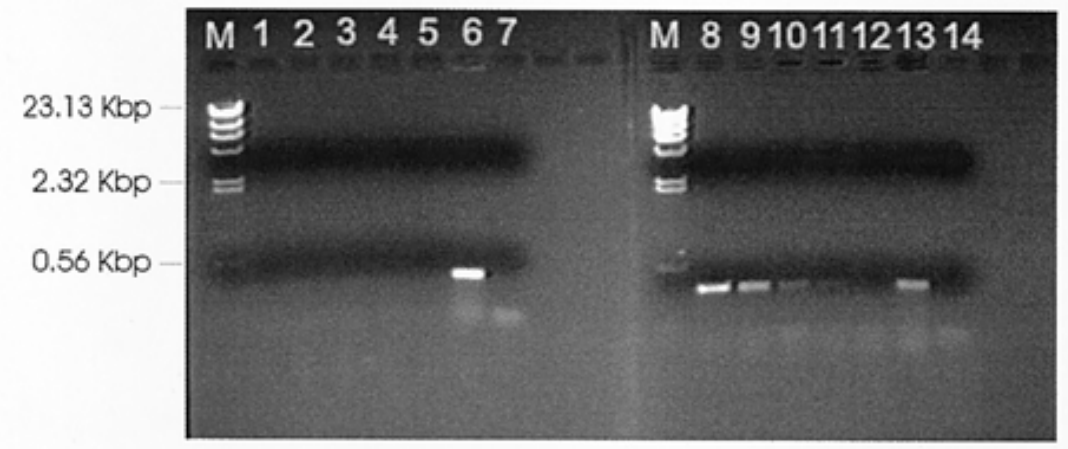

Fig. 1. Agarose gel image indicating the results of one repetition of an experiment to determine the threshold of detection of Pantoea ananatis by direct polymerase chain reaction (PCR) (i.e., PCR conducted on $2-\mu l$ samples of onion seed wash) versus immunomagnetic separation and PCR (IMSPCR) (i.e., PCR on cells captured on small magnetic polystyrene beads coated with antibodies specific to $P$. ananatis) in sterile onion seed wash with different concentrations of $P$. ananatis. In all cases, primers PanITS1 and EC5 were used. Lanes labeled M contain DNA size markers consisting of $\lambda$ phage DNA digested with HindIII restriction enzyme. Lanes 1 to 5 contain $10 \mu \mathrm{l}$ of PCR amplification products generated from the DNA contained in $2 \mu \mathrm{l}$ of sterile seed wash with approximately $10^{4}$ (CFU were too numerous to count), $1.5 \times 10^{3}, 3.5 \times 10^{2}, 50$, and $0 \mathrm{CFU} / \mathrm{ml}$ of $P$. ananatis as template DNA, respectively. Lanes 6 and 13, and 7 and 14 contain the results of PCR on $2 \mu$ of $P$. ananatis cell lysate containing target DNA and $2 \mu \mathrm{l}$ of sterile water as positive and negative controls, respectively. Lanes 8 to 12 contain the results of IMS-PCR conducted on the same samples in lanes 1 to 5 . Lanes 13 and 14 represent positive and negative control samples described earlier.

Table 2. Frequency of positive detections of Pantoea ananatis in onion seed wash spiked with different levels of the bacterium and tested using immunomagnetic separation and polymerase chain reaction (IMS-PCR) and by IMS followed by plating on nutrient agar ${ }^{\mathrm{a}}$

\begin{tabular}{|c|c|c|}
\hline $\begin{array}{l}\text { Average } P \text {. ananatis concen- } \\
\text { tration in onion seed wash } \\
\text { suspensions }(\mathrm{CFU} / \mathrm{ml})\end{array}$ & $\begin{array}{l}\text { Frequency of detection } \\
\text { by } \operatorname{IMS-PCR}^{\mathbf{b}}(\%)\end{array}$ & $\begin{array}{c}\text { Frequency of detection } \\
\text { by IMS-platingc }(\%)\end{array}$ \\
\hline $10^{4 \mathrm{~d}}$ & $100(12 / 12)$ & $100(12 / 12)$ \\
\hline $2.3 \times 10^{3}$ & $72.7(8 / 11)$ & $100(12 / 12)$ \\
\hline $3.9 \times 10^{2}$ & $54.5(6 / 11)$ & $90.9(10 / 11)$ \\
\hline 33 & $25(3 / 12)$ & $83.3(10 / 12)$ \\
\hline 0 & $0.0(0 / 12)$ & $0.0(0 / 12)$ \\
\hline
\end{tabular}

a Percentages of detection frequencies were determined based on 12 repetitions.

${ }^{\mathrm{b}}$ IMS-PCR is the technique by which small magnetic polystyrene beads coated with antibodies specific to a target cell are used to selectively capture target cells from heterogeneous mixtures. Cells captured by IMS are then rinsed to eliminate inhibitory compounds and lysed by boiling for 15 min. The DNA released from captured target cells is amplified by PCR using primers PanITS1/EC5.

${ }^{c}$ IMS-plating is the technique by which target cells sequestered by IMS are spread onto nutrient agar and incubated for $48 \mathrm{~h}$ at $28^{\circ} \mathrm{C}$. Bacteria are then identified by colony morphology and subsequent confirmatory tests.

${ }^{\mathrm{d}} \mathrm{CFU}$ recovered from cell suspensions were too numerous to determine accurately. ter) lined with two layers of sterile blotter paper (Hoffman Manufacturing Inc., Albany, OR) saturated with sterile deionized water. The petri dishes were placed into transparent plastic boxes containing sterile blotter paper saturated with a sterile solution $(50 \% \mathrm{vol} / \mathrm{vol})$ of glycerol. This generated conditions of $100 \%$ relative humidity to promote symptoms of center rot. The plastic boxes were closed and incubated under conditions of $25^{\circ} \mathrm{C}$ with continuous fluorescent light for 7 days. The percentage of seeds that germinated and the numbers of seedlings expressing symptoms of center rot were enumerated. To determine the statistical significance of the effects of $P$. ananatis infection on seed germination, analysis of variance was conducted on the percent germination of infested and noninfested seedlots.

\section{RESULTS}

IMS-PCR assay development. The polyclonal anti-PNA antibodies reacted with $P$. ananatis with indirect ELISA but also reacted with 17 of the 24 other bacteria evaluated (Table 1). However, the primer set PanITS1/EC5 demonstrated a high level of specificity to $P$. ananatis. Of the 28 bacteria tested, PCR amplicons measuring $398 \mathrm{bp}$ were produced only with DNA from $P$. ananatis and $P$. stewartii subsp. stewartii.

Sensitivity of IMS-PCR and IMSplating. The detection threshold of the direct PCR assay for the target bacterium, $P$. ananatis, in sterile HPLC-grade water ranged from $10^{1}$ to $10^{4} \mathrm{CFU} / \mathrm{ml}$ (data not shown). However, the direct PCR assay was unable to detect the target bacterium suspended in sterile onion seed wash (Fig. 1). This was expected, as seeds and other plant tissues have been previously reported to contain compounds that inhibit PCR $(11,24)$. In contrast, IMS eliminated inhibitory compounds to yield PCR-quality DNA (Fig. 1). Onion seed extracts containing ca. $10^{4}$ P. ananatis $\mathrm{CFU} / \mathrm{ml}$ were detected as positive for the bacterium $100 \%$ of the time by IMS-PCR (12/12 replications of the experiment). $P$. ananatis was detected in seed wash suspensions spiked to ca. 2.3 $\times 10^{3} \mathrm{CFU} / \mathrm{ml}$ in $72.7 \%$ (8/11) replications of the experiment (Table 2). As the concentration of $P$. ananatis decreased, the frequency of detection declined from $54.5 \%$ for samples with $3.9 \times 10^{2} \mathrm{CFU} / \mathrm{ml}$ to $25 \%$ for samples containing ca. $33 \mathrm{CFU} / \mathrm{ml}$ (Table 2). In control samples to which no target bacteria were added, IMS-PCR did not yield an amplicon. At all concentrations of $P$. ananatis evaluated, IMS-plating recovered colonies of $P$. ananatis from onion seed wash (Fig. 2). However, as the concentration of target bacteria decreased from $10^{4}$ to $0 \mathrm{CFU} / \mathrm{ml}$, the percentage of positive detections declined from 100 to $83.3 \%$ (Table 2). Analysis of variance indicated that the differences between CFU recovered by direct plating (100 $\mu \mathrm{l}$ of 
spiked seed wash) and IMS-plating (10 $\mu \mathrm{l}$ of rinsed IMBs) were not statistically significant $(P=0.24)$. This indicated that the IMBs retained the bacterial CFU after multiple rinses and facilitated a 10-fold concentration of target cells. In seed wash samples containing ca. $10 \mathrm{P}$. ananatis $\mathrm{CFU} / \mathrm{ml}$, the numbers of colonies recovered by IMS ranged from 0 to 12 , as opposed to 0 to 9 for direct plating. Additionally, in one attempt, while direct plating did not recover target CFU from seed wash spiked with $10^{1} \mathrm{CFU} / \mathrm{ml}$, IMS recovered 12 CFU.

Detection of $P$. ananatis in naturally infested onion seed. Of 76 umbels harvested from onion research plots with natural outbreaks of center rot, 15 (nine and six from the Blackshank and Horticulture plots, respectively) were found to be infested with $P$. ananatis by IMS-plating (Table 3). Only six seedlots (five and one from the Blackshank and Horticulture farms, respectively) were detected as being infested by IMS-PCR (Table 3). In all seedlots determined to be infested, colonies were recovered and the identities of these bacteria were confirmed by PCR with PanITS1/EC5 primers, fatty acid methyl ester analysis (similarity index values $=0.25$ to 0.79 ), and indole production. While IMS-plating detected more positive seedlots than IMS-PCR, all lots that tested positive by IMS-PCR were confirmed as $P$. ananatis by subsequent recovery of the pathogen. On the other hand, $64.4 \%(29 / 45)$ of $P$. ananatis-like colonies recovered by IMS-plating were not verified to be $P$. ananatis. In considering only the seedlots from which $P$. ananatis colonies were recovered and confirmed, there were no statistically significant differences between the infested seedlots recovered from Blackshank and Horticulture farms $(P=0.0122)$. Additionally, the difference between the numbers of $P$. ananatis-infested seedlots determined by IMS-PCR and IMS followed by plating on nutrient agar were not statistically significant $(P=0.0134)$.

Seed germination and disease transmission. The germination percentages of the seedlots were low, ranging from 0 to $66 \%$. Mean germination was 22.54 and $29.01 \%$ for seedlots infested and noninfested with $P$. ananatis, respectively. The differences in germination between infested and noninfested seedlots were not statistically significant $(P=0.28)$, suggesting that infestation with $P$. ananatis had no effect on seed germination. Despite this, the percentage of seedlots from which the pathogen was transmitted to seedlings resulting in center rot was $10.5 \%$ (53\% of infested seedlots). Shortly after germination, infected seedlings turned tan to dark brown and collapsed. A yellow bacterial ooze was present on the surfaces of some infected seedlings, and plants were dead within 8 days. Bacterial colonies recovered from infected onion seedlings were confirmed as $P$. ananatis using the techniques described previously.

\section{DISCUSSION}

Center rot represents a potential threat to onion production in Georgia. This paper provides evidence that the causal agent of center rot, $P$. ananatis, is both seedborne and seed-transmitted, which suggests that seed may be important in disseminating the pathogen. The IMS-PCR assay, which employs polyclonal antibodies and speciesspecific primers, represents a highly efficient and sensitive technique by which $P$. ananatis may be detected and isolated from onion seed. The detection threshold of the IMS-PCR assay using PanITS1/EC5 primers and anti-PNA antibodies was comparable to a similar assay developed for Acidovorax avenae subsp. citrulli in watermelon seeds (24). However, the assay developed for $P$. ananatis appears to be less reliable at low populations of the target pathogen. For cell suspensions containing $10 \mathrm{CFU} / \mathrm{ml}$ of seed wash, the A. avenae subsp. citrulli assay detected the pathogen in $42.8 \%(3 / 7)$ of the repetitions (24) compared with $25 \%$ for the $P$. ananatis assay. The performance of the two assays cannot be compared directly, but in both cases efforts must be made to improve the reliability of detecting low populations of target pathogens.

One area of concern for developing IMS-PCR for $P$. ananatis was the lack of specificity of the polyclonal antibody. However, since the role of the antibody in the IMS-PCR assay is to capture rather than detect the pathogen, the lack of antibody specificity did not affect the assay negatively. A low specificity antibody might even enhance sensitivity by allowing the capture of a wide range of putative target bacteria that could subsequently be screened by PCR with more specific primers. Alternatively, a low specificity capture antibody could also reduce the sensitivity of the assay if nontarget cells outnumber target cells. Based on the results of this study, however, this did not appear to be a

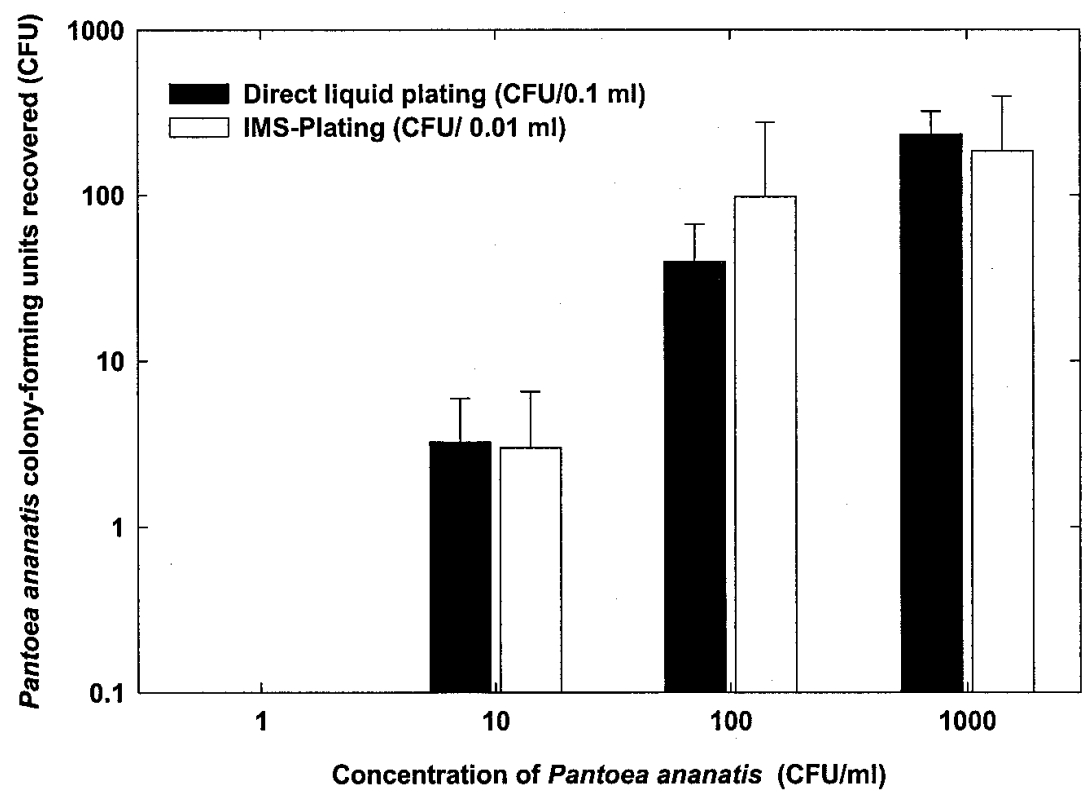

Fig. 2. Mean CFU recovered by direct liquid plating $(100 \mu \mathrm{l})$ on nutrient agar and immunomagnetic separation, followed by resuspension of immunomagnetic beads in $10 \mu \mathrm{l}$ of buffer and plating on nutrient agar, from sterile onion seed wash spiked with levels of Pantoea ananatis ranging from 0 to $10^{3} \mathrm{CFU} / \mathrm{ml}$. P. ananatis CFU recovered from cell suspensions with $10^{4} \mathrm{CFU} / \mathrm{ml}$ of onion seed wash were not included in this graph because they were too numerous to count accurately. Averages were generated based on 12 repetitions of the experiment. Error bars represent one standard deviation.

Table 3. Percentage of onion seedlots harvested in 2000 from two research plots in Tifton, GA, and determined to be infested by immunomagnetic separation and the polymerase chain reaction (IMSPCR) using polyclonal antibodies produced against Pantoea ananatis and primers PanITS1/EC5 and by IMS followed by plating on nutrient agar and incubation at $28^{\circ} \mathrm{C}$ for $48 \mathrm{~h}$

\begin{tabular}{lccc}
\hline Seed source & $\begin{array}{c}\text { Number of } \\
\text { seedlots }\end{array}$ & $\begin{array}{c}\text { Infested seedlots detected } \\
\text { by IMS-PCR }(\boldsymbol{\%})^{\mathbf{a}}\end{array}$ & $\begin{array}{c}\text { Infested seedlots detected } \\
\text { by IMS-plating }(\boldsymbol{\%})^{\mathbf{b}}\end{array}$ \\
\hline Horticulture & 43 & $2.33(1)$ & $13.95(6)$ \\
Blackshank & 33 & $15.15(5)$ & $27.27(9)$ \\
Total & 76 & $7.89(6)$ & $19.74(15)$ \\
\hline
\end{tabular}

a PCR results confirmed by subsequent recovery of $P$. ananatis colonies on nutrient agar followed by confirmatory PCR with PanITS1/EC5, indole production, and fatty acid methyl ester analysis.

${ }^{\mathrm{b}} P$. ananatis colonies confirmed by PCR with PanITS1/EC5 primers, indole production, and fatty acid methyl ester analysis. 
problem. While efforts are ongoing to identify a more specific capture antibody, the IMS-PCR assay evaluated in this study successfully facilitated the detection and recovery of $P$. ananatis from naturally infested onion seeds.

IMS-PCR and IMS-plating consistently demonstrated detection and recovery thresholds of $10^{1}$ to $10^{4} \mathrm{CFU} / \mathrm{ml}$ of spiked seed wash. The IMS-PCR assay allows rapid and efficient amplification of bacterial DNA in the presence of inhibitory compounds in the seed wash. Therefore, IMS may be important in managing center rot by allowing the screening and exclusion of infested seedlots from seedbeds and commercial production fields. The results of this study indicate that IMS followed by plating on nutrient agar was more sensitive than the IMS-PCR assay at detecting populations of $P$. ananatis in infested seedlots. IMS-plating detected target bacteria in $83.3 \%$ of the attempts conducted on seed wash suspensions containing $10 \mathrm{CFU}$ of $P$. ananatis per milliliter as opposed to $25 \%$ for the IMS-PCR assay. Additionally, use of IMS-plating enabled detection of $P$. ananatis in $150 \%$ more naturally infested seedlots than did the IMS-PCR assay. However, IMS-plating is still less efficient time-wise than IMS-PCR because $48 \mathrm{~h}$ are required after plating to observe colony morphology. Furthermore, staff carrying out IMS-plating must be trained to recognize colonies of $P$. ananatis, sometimes in the presence of numerous contaminating, saprophytic bacterial colonies. IMS-plating on selective media, selective enrichment prior to IMS-PCR, or IMS followed by BIO-PCR (22) may be options for improving the sensitivity and reliability of IMS assays for seedborne bacterial pathogens. However, due to similarities in patterns of substrate utilization and tolerances to antibiotics and inhibitors, it is unlikely that a selective medium could be developed to discriminate between $P$. agglomerans and P. ananatis.

Despite observing infestation by $P$. ananatis of onion seedlots harvested from naturally infested fields, the significance of seedborne $P$. ananatis remains uncertain. Onion seeds are not produced routinely in Georgia because of climatic conditions that favor disease development. Hence, it cannot be assumed that natural infection occurs under the production climates found in the more arid regions where seeds are produced. Nevertheless, the observation of seed infestation and seedling transmission of $P$. ananatis is significant, and infested seeds should be considered a potentially important stage in the epidemiology of center rot. The fact that there were no obvious center rot symptoms on mother plants from which the seeds were harvested suggests that visual inspection of seed production fields may be of limited utility in ensuring $P$. ananatis-free onion seeds. However, this observation along with other seedborne aspects of this disease must be studied in greater detail to determine the significance of seeds as primary sources of inoculum. According to a recent survey conducted by Gitaitis et al. (8), $P$. ananatis is widely distributed throughout Georgia on many types of weed hosts including carpetweed (Mollugo verticillata), common ragweed (Ambrosia artemisiifolia), crabgrass (Digitaria sanguinalis), common cocklebur (Xanthium pensylvanicum), curly dock (Rumex crispus), Florida pusley (Richardia scabra), sicklepod (Cassia obtusifolia), stinkweed (Thlaspi arvense), Texas panicum (Panicum texanum), vaseygrass (Paspalum urvillei), wild radish (Brassica spp.), and yellow nutsedge (Cyperus esculentus). While epiphytic bacterial populations on weeds can serve as primary sources of inoculum, this observation does not appear to account for the recent and sporadic occurrences of center rot in Georgia, nor the concurrent outbreaks of center rot in Michigan and Colorado. It is possible that strains of $P$. ananatis ubiquitous in Georgia are significantly different from strains of $P$. ananatis causing center rot and are incapable of inciting disease on onions under natural conditions.

The results of this study do not provide information on the effects of $P$. ananatis on germination of onion seedlings. Both infested and noninfested seedlots evaluated in this study had low germination percentages. The seeds may have been immature when harvested or may have been handled and stored in a manner that reduced seed germination. The effects of $P$. ananatis on seed quality will be addressed more directly in future studies. The results of this study indicate that onion seeds are a potential source of inoculum for development of center rot. Research must be initiated to determine the epidemiological significance of seedborne inoculum and efficient methods to eliminate this threat to onion production in Georgia and other states.

\section{ACKNOWLEDGMENTS}

Funding for this research was provided by the Vidalia Onion Committee and USDA/CSREES Grant No. 99-34389-7437, entitled "Integrated Disease Management to Improve the Quality of Sweet Onions in Georgia."

\section{LITERATURE CITED}

1. Audy, P., Braat, C. E., Saindon, G., Huang, H. C., and Laroche, A. 1996. A rapid and sensitive PCR-based assay for concurrent detection of bacteria causing common and halo blights in bean seed. Phytopathology 86:361-366.

2. Azad, H. R., Holmes, G. J., and Cooksey, D. A. 2000. A new leaf blotch disease of sudangrass caused by Pantoea ananas and Pantoea stewartii. Plant Dis. 84:973-979.

3. Bruton, B. D., Wells, J. M., and Lester, G. E. 1986. Pathogenicity of Erwinia ananas to muskmelons in Texas. (Abstr.) Phytopathology 76:1136.

4. Bruton, B. D., Wells, J. M., Lester, G. E., and Patterson, C. L. 1991. Pathogenicity and characterization of Erwinia ananas causing a postharvest disease of cantaloup fruit. Plant
Dis. 75:180-183.

5. Gillaspie, A. G., Jr., Pittman, R. N., Pinnow, D. L., and Cassidy, B. G. 2000. Sensitive method for testing peanut seed lots for Peanut stripe and Peanut mottle viruses by immunocapture-reverse transcription-polymerase chain reaction. Plant Dis. 84:559-561.

6. Gitaitis, R. D., and Beaver, R. W. 1990. Characterization of fatty acid methyl ester content of Clavibacter michiganensis subsp. michiganensis. Phytopathology 80:318-321.

7. Gitaitis, R. D., and Gay, J. D. 1997. First report of a leaf blight, seed stalk rot, and bulb decay of onion by Pantoea ananas in Georgia. Plant Dis. 81:1096

8. Gitaitis, R. D., Zolobowska, L., Culpepper, S., Langston, D., and Walcott, R. 2000. Polymerase chain reaction detection of the onion pathogen Pantoea ananatis on various weeds and crops in Georgia, USA. Pages 406-408 in: Proc. Int. Conf. Plant Pathogenic Bacteria, 10th. P1. Charlottetown, Prince Edward Island, Canada. S. H. De Boer, ed. Kluwer Academic Publishers, Dordrecht, Netherlands.

9. Gurtler, V., and Stanisich, V. A. 1996. New approaches to typing and identification of bacteria using the 16S-23S rDNA spacer region. Microbiology 142:3-16.

10. Hadas, R., Kritzman, G., Gefen, T., and Manulis, S. 2001. Detection, quantification and characterization of Erwinia carotovora ssp. carotovora contaminating pepper seeds. Plant Pathol. 50:117-123.

11. Hartung, J. S., Pruvost, O. P., Villemot, I., and Alvarez, A. 1996. Rapid and sensitive colorimetric detection of Xanthomonas axonopodis pv. citri by immunocapture and a nestedpolymerase chain reaction assay. Phytopathology 86:95-101.

12. Hattingh, M. J., and Walters, D. F. 1981. Stalk and leaf necrosis of onion caused by Erwinia herbicola. Plant Dis. 65:615-618.

13. Hugh, R., and Leifson, E. 1953. The taxonomic significance of fermentative versus oxidative metabolism of carbohydrates by various Gram negative bacteria. J. Bacteriol. 66:24-26.

14. Iimura, K., and Hosono, A. 1994. Identification of Gram-negative bacteria isolated from buckwheat seeds. J. Food Hyg. Soc. Jpn. 35:525-529.

15. Iimura, K., and Hosono, A. 1996. Biochemical characteristics of Enterobacter agglomerans and related strains found in buckwheat seeds. Int. J. Food Microbiol. 30:243-253.

16. Lim, W. H. 1986. Bacterial diseases of pineapple. Rev. Trop. Plant Pathol. 2:127-140.

17. McLaughlin, R. J., and Chen, T. A. 1990. ELISA methods for plant pathogenic prokaryotes. Pages 197-204 in: Serological Methods for Detection and Identification of Viral and Bacterial Plant Pathogens. R. Hampton, E. Ball, and S. DeBoer, eds. American Phytopathological Society, St. Paul, MN.

18. Mergaert, J., Verdonck, L., and Kersters, K. 1993. Transfer of Erwinia ananas (synonym, Erwinia uredovora) and Erwinia stewartii to the genus Pantoea emend as Pantoea ananas (Serano 1928) comb. nov. and Pantoea stewartii (Smith 1898) comb. nov., respectively and description of Pantoea stewartii subsp. indologenes subsp. nov. Int. J. Syst. Bacteriol. 43:162-173.

19. Pasquini, G., Simeone, A. M., Conte, L., and Barba, M. 1998. Detection of plum pox virus in apricot seeds. Acta Virol. 42:260-263.

20. Safarik, I., and Safarikova, M. 1999. Use of magnetic techniques for the isolation of cells. J. Chromatogr. 722:33-53.

21. Sasser, J. M., Fieldhouse, D. J., and Carter, C. N. 1984. Computer assisted identification of bacteria based on fatty acid analysis. (Abstr.) Phytopathology 74:882. 
22. Schaad, N. W., Cheong, S. S., Tamaki, S., Hatziloukas, E., and Panopoulos, N. J. 1995. A combined biological and enzymatic amplification (BIO-PCR) technique to detect Pseudomonas syringae pv. phaseolicola in bean seed extracts. Phytopathology 85:243-248.

23. Schwartz, H. F., and Otto, K. 2000. First report of a leaf blight and bulb decay of onion by Pantoea ananatis in Colorado. Plant Dis. 84:808.
24. Walcott, R. R., and Gitaitis, R. D. 2000. Detection of Acidovorax avenae subsp. citrulli in watermelon seed using immunomagnetic separation and the polymerase chain reaction. Plant Dis. 84:470-474. 